\title{
EFFECT OF SEAWEED APPLICATION ON NUTRIENT UPTAKE OF STRAWBERRY CV. ALBION GROWN UNDER THE ENVIRONMENTAL CONDITIONS OF NORTHERN IRAQ
}

\author{
AL-SHATRI, A. H. N. ${ }^{1}-$ PAKYÜREK, M. ${ }^{1 *}-$ YAVIÇ, A. $^{2}$ \\ ${ }^{1}$ Siirt University Faculty of Agriculture, Department of Horticulture, 56100 Siirt, Turkey \\ ${ }^{2}$ Yüzüncü Yll University Faculty of Agriculture, Department of Horticulture, 65080 Van, Turkey \\ ${ }^{*}$ Corresponding author \\ e-mail:mine.pakyurek@siirt.edu.tr
}

(Received 22 $2^{\text {nd }}$ Aug 2019; accepted $15^{\text {th }}$ Nov 2019)

\begin{abstract}
This pot experiment was carried out to investigate the effects of four doses $\left(0,2,4\right.$ and 8 g.L $\left.\mathrm{L}^{-1}\right)$ of seaweed extract (Alga 600) application with fertigation on nutrient uptake of strawberry cv. Albion during the 2016-2017 vegetation period in Kalar city located in Northern Iraq. The results of leaf analysis indicated significant $(\mathrm{p}<0.01)$ differences at the nitrogen $(\mathrm{N})$, phosphorus $(\mathrm{P})$, potassium $(\mathrm{K})$, magnesium $(\mathrm{Mg})$, calcium $(\mathrm{Ca})$, manganese $(\mathrm{Mn})$ and iron $(\mathrm{Fe})$ concentrations between two sampling periods. In contrast, copper $(\mathrm{Cu})$ and zinc $(\mathrm{Zn})$ concentrations of plants leaves did not significantly differed between the sampling periods. According to the statistical analysis, the effect of seaweed doses on nutrients were statistically insignificant for all nutrients except Mn ( $>0.05$ ). While for the Mn element, the highest value $\left(223.70 \pm 11.59 \mathrm{mg} \mathrm{kg}^{-1}\right)$ obtained from T4 $\left(8 \mathrm{~g} . \mathrm{L}^{-1}\right)$ seaweed dose; the lowest one $(164.91 \pm 11.59$ $\mathrm{mg} \mathrm{kg}^{-1}$ ) obtained from control dose. The effect of interaction between seaweed doses and periods on nutrients was also not found statistically significant ( $p>0.05$ ). In general, seaweed extract of 8 g.L. $\mathrm{L}^{-1}$ was more effective on macro and micro nutrient contents of strawberry leaves.
\end{abstract}

Keywords: Fragaria $x$ ananassa Duch, $c v$. Albion, organic fertigation, algae extract, plant nutrients

\section{Introduction}

Strawberry (Fragaria $\mathrm{x}$ ananassa Duch) belonging to family Rosaceae, is one of the most delicious and refreshing temperate fruits of the world. It has rich source of vitamins and minerals with delicate flavor (Sharma, 2002) and gives early and very high returns per unit area compared to the other fruits because the fruits are ready for harvest within six months of the planting (Katiyar et al., 2009). Wood strawberry (Fragaria vesca) and musky strawberry (Fragaria moschata) had been cultivated in Europe and Russia for centuries before the breeding of Fragaria $x$ ananassa. In the early 1700s, inter-planting of Fragaria virginiana (male) with Fragaria chiloensis (female) in France led to the production of hybrid seedlings known as Pineapple or Pine strawberry plants, which are the progenitors of the new cultivated strawberry plant (Fragaria x ananassa Duch) (Darrow, 1966).

Several factors constrain agricultural production by negatively affecting the plant growth. Soil characteristics determining the fertility of soils on which the plant is grown and the climatic characteristics such as temperature and humidity positively or negatively affect the crop production. Seaweed is used in many countries as liquid extract or mixing directly with the soil. The seaweed, an organic amendment regulates the soil structure when mixed directly into the soil and sustains the productivity for a long time. Some seaweeds have been used as fertilizers in the production areas for many years (Güner and Aysel, 1996). Seaweed extracts have been used extensively in organic 
farming especially in developed countries due to the reducing storage losses, increasing the production, uptake of inorganic nutrients from soil, seed germination, resistance to stress conditions, diseases and pests (Blunden, 1991). Seaweed increases nutrient and water uptake by providing strong root development of plants and encourages vegetative growth by accelerating the formation of chlorophyll. In addition, yield and quality of the products are improved by increasing the balanced and long-term uptake of macro and micro nutrients from the soil; thus, the market and export value of the product are increased (Blunden et al., 1992; Hong et al., 1995). Seaweed extracts increase the uptake of micro elements by chelating the micronutrients. Side branching and fruit formation in fruit trees also have been increased with seaweed application. In addition, flower and fruit losses have been decreased and yield increased up to $30 \%$. Seaweeds also have been reported to increase the impacts of pesticides by $25 \%$ (Blunden et al., 1992).

Seas are generally covered with various qualities and numbers of seaweeds from the surface to a depth of $1000 \mathrm{~m}$. The distribution of seaweeds, whose nutritional and other economic values have been documented, in the seas vary greatly depending on the water compositions of seas and the climate characteristics of the region (Blunden, 1991). Several types of compounds such as macro and micro elements (N, Ca, $\mathrm{Mg}, \mathrm{Mn}, \mathrm{B}, \mathrm{Br}$, $\mathrm{I}, \mathrm{Zn}, \mathrm{Cu}$ and $\mathrm{Co}$ ), plant growth regulators (auxin, cytokinin, gibberellin and abscisic acid) and betaines are responsible from the positive effects of seaweeds (Hong et al., 1995).

In this study, a potting experiment with four different doses of seaweed extract, including the control treatment, was carried out to investigate the effect of seaweed, an organic fertilizer, on plant growth and nutrient uptake of Albion strawberry cultivar. This is a pioneering study that will serve to expand the production of strawberry which has not yet been cultivated widespread in Iraq.

\section{Materials and Methods}

The study was carried out during the vegetation period of 2016-2017 with pots in an open area of Kalar city located at Sulaymaniyah governate in Northern Iraq. The experimental site is situated between $34.62131^{\circ}$ north latitude and $45.31961^{\circ}$ east longitude at $200 \mathrm{~m}$ above sea level. The minimum and the maximum temperatures in Kalar during the vegetation period were $-3^{\circ} \mathrm{C}$ and $35^{\circ} \mathrm{C}$ (Anonymous, 2017). The temperature started to increase in the middle of the April; thus, the effects of high temperature on size and weight of strawberry fruits appeared at the beginning of May, which was the last harvest time (Table 1).

Table 1. Climate data of Kalar-Sulaymaniyah, Iraq from January to June 2017.

\begin{tabular}{c|c|c|c|c|c|c}
\hline & \multicolumn{3}{|c|}{ Temperature $\left({ }^{\circ} \mathbf{C}\right)$} & \multicolumn{3}{c}{ Relative Humidity (\%) } \\
\hline Months & Average & Maximum & Minimum & Average & Maximum & Minimum \\
\hline January & 8.72 & 20.3 & -2.98 & 88.19 & 100 & 0.89 \\
February & 12.62 & 25.73 & 0.92 & 73.59 & 100 & 0.9 \\
March & 15.7 & 28.22 & 2.47 & 65.59 & 100 & 0.9 \\
April & 21.01 & 38.4 & 5.53 & 9.71 & 100 & 0.89 \\
May & 27.49 & 41.91 & 13.66 & 15.27 & 100 & 0.92 \\
June & 33.51 & 46.95 & 17.49 & 21.13 & 56.45 & 7.33 \\
\hline
\end{tabular}




\section{Experimental Details}

The plant material used in the experiment was Albion variety which was registered in 2006 by the University of California and sent out to the world. Despite the low yield of the Albion variety, the farmers report from the Mid-Atlantic on fruit quality are positive. The Albion variety has firm fruits with a high marketable yield percentage due to the shape and volume of the fruits. The ideal color and acceptable flavor of strawberry fruits are obtained at maturity. The Albion variety is very strong, and produces a high number of daughter plants and stolons (Lantz et al., 2010) (Figure 1).
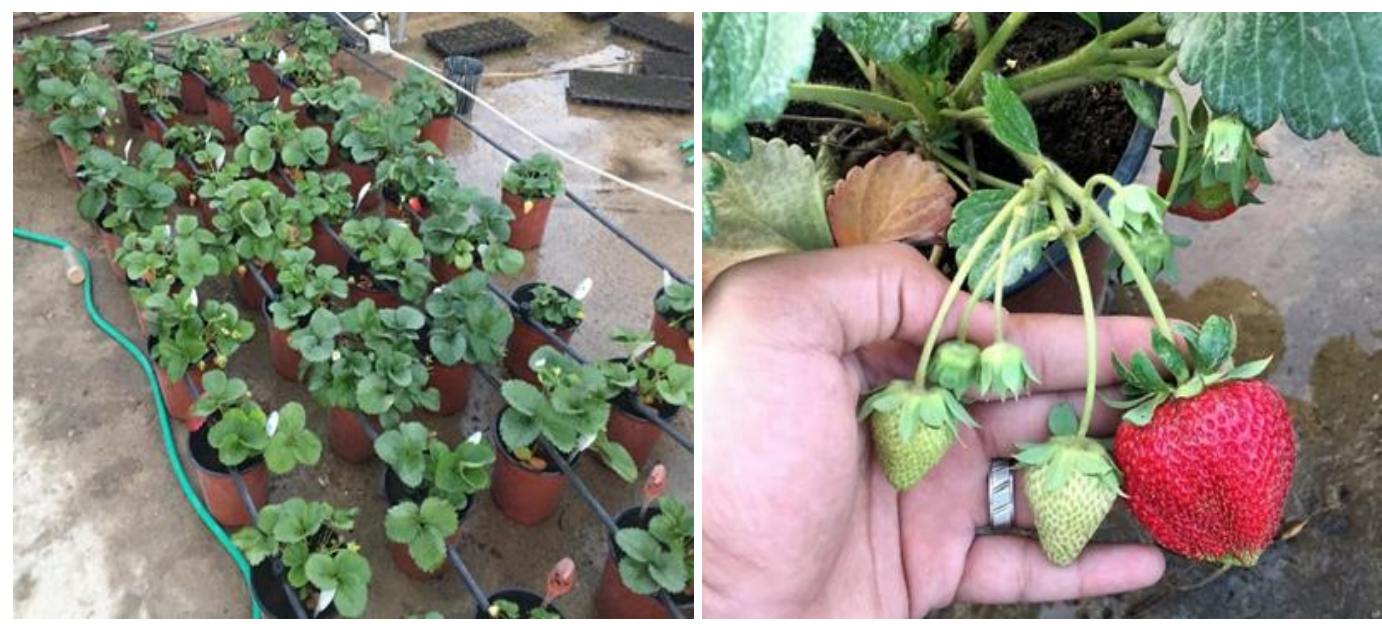

Figure 1. Strawberry plants and fruits of cv. Albion.

The seedlings used in the experiment were obtained on January $1^{\text {st }}, 2017$ from Antalya province, Turkey. The pot experiment laid out based on the randomized plot design with three replicates. The pots were filled with $5 \mathrm{~kg}$ peat moss, watered with drip system and placed to an open area on January $15^{\text {th }}, 2017$ in Kalar district. Full flowering time was on $15^{\text {th }}$ February 2017, first harvesting time was on $20^{\text {th }}$ March and second one was on $12^{\text {th }}$ May 2017 in our experiment. Four different doses $\left(0,2,4\right.$ and 8 g.L $\left.\mathrm{L}^{-1}\right)$ of fertigation solutions were prepared from the seaweed (Alga 600). Based on the literature information, we applied three different doses (except control) starting from $2 \mathrm{~g} . \mathrm{L}^{-1}$ and increasing in double doses thought to will be obtained effective results in the study. The seaweed was dissolved in $22^{\circ} \mathrm{C}$ water for better absorption. The prepared solutions were applied to the plants twice. First application was applied in the full flowering stage (after the formation of first fruits) and second one was applied 20 days later then previous one, in other words, after the first harvesting time. The fertigation was applied in the morning. Components of seaweed were shown in Table 2.

\section{Nutrient Analysis of Strawberry Leaves}

Twelve (Four seaweed applications with three repetitions) leaf sample bags (each bag contains three leaves) with two replications (two fertigation times) were prepared during the flowering stage and after the first harvest to determine the plant nutrient concentrations. Leaves were washed in tap water and rinsed with distilled water then left for drying in oven at $60^{\circ} \mathrm{C}$ for 48 hours. The dried samples were ground by milling and stored in pouch papers until the chemical analysis. Plant nutrient concentration of 
samples was determined by using the methods reported by Kaçar and Inal (2008). Nitrogen $(\mathrm{N})$ concentration was determined by Kjeldahl method. Phosphorus (P), potassium $(\mathrm{K})$, magnesium $(\mathrm{Mg})$, calcium $(\mathrm{Ca})$, manganese $(\mathrm{Mn})$ and iron $(\mathrm{Fe})$ copper $(\mathrm{Cu})$ and zinc $(\mathrm{Zn})$ concentrations were analyzed by microwave method using an ICP-MS instrument (Thermo Scientific, ICAP Q model).

Table 2. Chemical composition of seaweed (Alga 600) used in the experiment.

\begin{tabular}{|c|c|c|}
\hline Chemical Composition & Unit & Content \\
\hline Nitrogen $(\mathrm{N})$ & & $0.5-1.0$ \\
\hline Alganic acid & & $6.0-9.0$ \\
\hline Sulfur (S) & & $1.0-1.5$ \\
\hline Phosphorus pentoxide $\left(\mathrm{P}_{2} \mathrm{O}_{5}\right)$ & & $6.0-9.0$ \\
\hline Calcium oxide $(\mathrm{CaO})$ & & $0.4-1.6$ \\
\hline Iron $(\mathrm{Fe})$ & $\%$ & $0.15-0.3$ \\
\hline Magnesium oxide $(\mathrm{MgO})$ & & 0.06 \\
\hline Potassium oxide $\left(\mathrm{K}_{2} \mathrm{O}\right)$ & & $21-24$ \\
\hline Amino acid & & 4.0 \\
\hline $\mathrm{pH}$ & & $9-11$ \\
\hline Organic matter & & $40-50$ \\
\hline
\end{tabular}

\section{Statistical Analysis}

The effects of seaweed doses and application periods on nutrient concentrations of strawberry leaves were assessed by the two-way analysis of variance test conducted according to the randomized plot design (ANOVA). Significance threshold was set to 0.05 and 0.01 levels. Paired samples t test was used to test the difference between the periods. Descriptive statistics such as mean and standard errors of nutrient contents were presented.

\section{Results and Discussion}

According to the results obtained in our study, increasing seaweed doses $(0,2,4$ and $8 \mathrm{~g} . \mathrm{L}^{-1}$ ) were increased the yield and fruit quality of the product. There is a significant increase in T4 (8 g. $\left.\mathrm{L}^{-1}\right)$ compared with control (T1) and T2 treatment. The fertigation with seaweed (Alga 600) in T4 treatment resulted in the maximum value of yield per plant $(\mathrm{g}) 295.03 \mathrm{~g}$ and per hectare $3278.18 \mathrm{~kg} / \mathrm{ha}$. The lowest value belongs to the control treatment. Moreover, the T4 dose $\left(8 \mathrm{~g} . \mathrm{L}^{-1}\right)$ gave the maximum value of the average volume of fruit $\left(18.88 \mathrm{ml}^{3}\right)$ and total volume of fruit $\left(329.37 \mathrm{ml}^{3}\right)$ and the lowest value recorded by control treatment. This records can be explained by the fact that seaweed application leads to the improvement in the development of fruit diameter, strength, and length in addition to a better rate of fruit production (Abdulraheem, 2009).

The essential elements are divided in two groups as macro and micro plant nutrients. Macro nutrients consist of $\mathrm{N}, \mathrm{P}, \mathrm{K}, \mathrm{Ca}$ and $\mathrm{Mg}$ which are used in large quantities; therefore, macro nutrients are very important for plant growth supplied by fertilizers. Micro nutrients are $\mathrm{Fe}, \mathrm{Cu}, \mathrm{Cl}, \mathrm{Bo}, \mathrm{Mn}$ and $\mathrm{Zn}$ which are used in small quantities by the plants though are necessary for plant essential. As a result of two-way analysis of variance, the effect of seaweed doses on nutrients was statistically insignificant for all nutrients except $\mathrm{Mn}(\mathrm{p}>0.05)$ (Table 3). The results of nutrient concentrations of 
strawberry leaf samples in flowering time and after the first harvest were given in Table 4. The effect of interaction between seaweed doses and periods on nutrients was also not found statistically significant ( $\mathrm{p}>0.05)$.

Table 3. Nutrient concentrations of plant leaves get from four several seaweed doses.

\begin{tabular}{|c|c|c|c|c|c|c|c|c|c|}
\hline \multirow{2}{*}{ Dose } & $\mathbf{N}$ & $\mathbf{P}$ & $\mathbf{K}$ & Mg & $\mathbf{C a}$ & Mn & $\mathbf{F e}$ & $\mathbf{C u}$ & Zn \\
\hline & \multicolumn{9}{|c|}{$\mathrm{mg} \mathrm{kg}^{-1}(\mathrm{ppm})$} \\
\hline $\mathrm{T} 1$ & $\begin{array}{c}3.13 \pm \\
0.13 \\
\end{array}$ & $\begin{array}{c}4329.42 \pm \\
258.25 \\
\end{array}$ & $\begin{array}{c}17877.93 \pm \\
1106.18\end{array}$ & $\begin{array}{c}5259.78 \pm \\
300.60 \\
\end{array}$ & $\begin{array}{c}921.16 \pm \\
49.64 \\
\end{array}$ & $\begin{array}{l}164.91 \pm \\
11.59 \mathrm{~b} \\
\end{array}$ & $\begin{array}{c}380.13 \pm \\
18.41 \\
\end{array}$ & $\begin{array}{c}3.61 \pm \\
0.20\end{array}$ & $\begin{array}{c}31.99 \pm \\
2.34 \\
\end{array}$ \\
\hline $\mathrm{T} 2$ & $\begin{array}{c}2.87 \pm \\
0.13\end{array}$ & $\begin{array}{c}3945.21 \pm \\
258.25\end{array}$ & $\begin{array}{c}18258.25 \pm \\
1106.18\end{array}$ & $\begin{array}{c}4818.04 \pm \\
300.60\end{array}$ & $\begin{array}{c}882.59 \pm \\
49.64\end{array}$ & $\begin{array}{l}178.01 \pm \\
11.59 \mathrm{ab}\end{array}$ & $\begin{array}{c}359.32 \pm \\
18.41\end{array}$ & $\begin{array}{c}3.12 \pm \\
0.20\end{array}$ & $\begin{array}{c}30.54 \pm \\
2.34\end{array}$ \\
\hline $\mathrm{T} 3$ & $\begin{array}{c}3.14 \pm \\
0.13\end{array}$ & $\begin{array}{c}3814.78 \pm \\
258.25 \\
\end{array}$ & $\begin{array}{c}17327.27 \pm \\
1106.18 \\
\end{array}$ & $\begin{array}{c}4805.63 \pm \\
300.60\end{array}$ & $\begin{array}{c}853.96 \pm \\
49.64 \\
\end{array}$ & $\begin{array}{l}180.17 \pm \\
11.59 \mathrm{ab} \\
\end{array}$ & $\begin{array}{c}379.59 \pm \\
18.41 \\
\end{array}$ & $\begin{array}{c}3.01 \pm \\
0.20\end{array}$ & $\begin{array}{c}30.21 \pm \\
2.34 \\
\end{array}$ \\
\hline $\mathrm{T} 4$ & $\begin{array}{c}2.94 \pm \\
0.13\end{array}$ & $\begin{array}{c}4277.42 \pm \\
258.25 \\
\end{array}$ & $\begin{array}{c}17857.60 \pm \\
1106.18 \\
\end{array}$ & $\begin{array}{c}4851.53 \pm \\
300.60\end{array}$ & $\begin{array}{c}887.16 \pm \\
49.64 \\
\end{array}$ & $\begin{array}{r}223.70 \pm \\
11.59 \mathrm{a} \\
\end{array}$ & $\begin{array}{c}385.73 \pm \\
18.41 \\
\end{array}$ & $\begin{array}{c}3.05 \pm \\
0.20\end{array}$ & $\begin{array}{c}30.46 \pm \\
2.34 \\
\end{array}$ \\
\hline Sig. (P value) & NS & NS & NS & NS & NS & $\mathrm{p}<0.05$ & NS & NS & NS \\
\hline
\end{tabular}

$\mathrm{p}<0.05$ : significant at 0.05 level; ns: not significantly different.

Table 4. Nutrient concentrations of plant leaves get from two fertigation periods.

\begin{tabular}{|c|c|c|c|c|c|c|c|c|c|}
\hline \multirow{2}{*}{ Periods } & $\mathbf{N}$ & $\mathbf{P}$ & $\mathbf{K}$ & Mg & $\mathbf{C a}$ & Mn & $\mathbf{F e}$ & $\mathbf{C u}$ & Zn \\
\hline & \multicolumn{9}{|c|}{$\mathrm{mg} \mathrm{kg}^{-1}(\mathrm{ppm})$} \\
\hline $\begin{array}{l}\text { Flowering } \\
\text { Stage }\end{array}$ & $\begin{array}{l}3.73 \pm \\
0.09 \mathrm{a}\end{array}$ & $\begin{array}{c}5657.78 \pm \\
182.61 \mathrm{a}\end{array}$ & $\begin{array}{c}20155.3 \pm \\
782.19 \mathrm{a}\end{array}$ & $\begin{array}{l}3380.43 \pm \\
212.56 \mathrm{~b}\end{array}$ & $\begin{array}{c}490.88 \pm \\
35.10 \mathrm{~b}\end{array}$ & $\begin{array}{c}131.30 \pm \\
8.19 \mathrm{~b}\end{array}$ & $\begin{array}{c}267.62 \pm \\
13.02 \mathrm{~b}\end{array}$ & $\begin{array}{c}3.17 \pm \\
0.14\end{array}$ & $\begin{array}{c}31.90 \pm \\
1.65\end{array}$ \\
\hline $\begin{array}{c}\text { After the } \\
\text { first } \\
\text { harvest }\end{array}$ & $\begin{array}{l}2.31 \pm \\
0.09 \mathrm{~b}\end{array}$ & $\begin{array}{c}2525.63 \pm \\
182.61 \mathrm{~b}\end{array}$ & $\begin{array}{l}15505.2 \pm \\
782.19 \mathrm{~b}\end{array}$ & $\begin{array}{c}6487.06 \pm \\
212.56 \mathrm{a}\end{array}$ & $\begin{array}{c}1281.56 \pm \\
35.10 \mathrm{a}\end{array}$ & $\begin{array}{c}242.09 \pm \\
8.19 \mathrm{a}\end{array}$ & $\begin{array}{c}484.77 \pm \\
13.02 \mathrm{a}\end{array}$ & $\begin{array}{c}3.22 \pm \\
0.14\end{array}$ & $\begin{array}{c}29.70 \pm \\
1.65\end{array}$ \\
\hline $\begin{array}{c}\text { Sig. } \\
\text { (P value) }\end{array}$ & $\mathrm{p}<0.01$ & $\mathrm{p}<0.01$ & $\mathrm{p}<0.01$ & $\mathrm{p}<0.01$ & $\mathrm{p}<0.01$ & $\mathrm{p}<0.01$ & $\mathrm{p}<0.01$ & NS & NS \\
\hline
\end{tabular}

$\mathrm{p}<0.01$ : significant at 0.01 level; NS: not significantly different.

\section{Macronutrient Contents of Strawberry Leaves}

The effect of different fertigation doses of seaweed (Alga 600) treatments on $\mathrm{N}$ concentration of strawberry leaves were presented in Figure 2. The highest $\mathrm{N}$ concentration was obtained with T3 seaweed treatment $\left(4\right.$ g. $\left.\mathrm{L}^{-1}\right)$, while the $\mathrm{N}$ concentration was sharply decreased with T4 treatment $\left(8 \mathrm{~g} . \mathrm{L}^{-1}\right)$ which caused to the lowest $\mathrm{N}$ concentration in leaves. The $\mathrm{N}$ concentration of leaves in the seaweed treatments after the second harvest was lower than the control treatment (T1). Sampling time had a significant effect on $\mathrm{N}$ concentration of leaves (Table 4). The $\mathrm{N}$ concentration recorded in the flowering stage $\left(3.73 \pm 0.09 \mathrm{mg} \mathrm{kg}^{-1}\right)$ was significantly higher than that obtained after the first harvest $\left(2.31 \pm 0.09 \mathrm{mg} \mathrm{kg}^{-1}\right)$. The differences in $\mathrm{N}$ concentration between the sampling periods was related to the higher consumption of $\mathrm{N}$ in fruiting stage compared to the flowering stage (Rathore et al., 2009). The results indicated that seaweed was not able to supply adequate $\mathrm{N}$ required by strawberry plants (Schmidt et al., 2003), though it may improve the root growth of plants. The results obtained were in agreement with those reported by Shehata et al. (2011). 


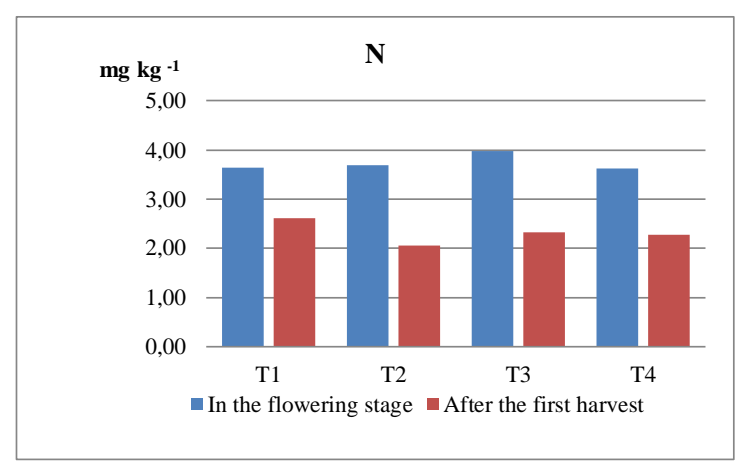

Figure 2. Nitrogen concentrations of strawberry leaves at two different sampling times for 4 different seaweed doses.

Phosphorus has several key plant functions, including energy transfer, photosynthesis, transformation of sugars and starches, nutrient movement within the plant and transfer of genetic characteristics between the generations (Blevins, 1999). Plants with high $\mathrm{P}$ content in leaves need high $\mathrm{P}$ supply for fruit production (Margarida et al., 2014). The effects of different doses of seaweed fertigation on $P$ concentration of strawberry leaves were shown in Figure 3. The P concentration in T2, T3 and T4 treatments did not significantly differ from the control treatment. The highest $\mathrm{P}$ concentration of strawberry leaves was recorded in T4 treatment at flowering stage and the lowest $\mathrm{P}$ concentration was in $\mathrm{T} 3$ treatment at flowering stage. The highest $\mathrm{P}$ value in the second sampling period was obtained in $\mathrm{T} 1$, while the lowest $\mathrm{P}$ value was in $\mathrm{T} 4$ treatment. The $\mathrm{P}$ concentration between two sampling periods was significantly different $(\mathrm{p}<0.01)$. The concentration of $\mathrm{P}$ in the flowering stage was significantly higher $\left(5657.78 \pm 182.61 \mathrm{mg} \mathrm{kg}^{-1}\right)$ than the $\mathrm{P}$ concentration recorded after the first harvest $\left(2525.63 \pm 182.61 \mathrm{mg} \mathrm{kg}^{-1}\right)$.

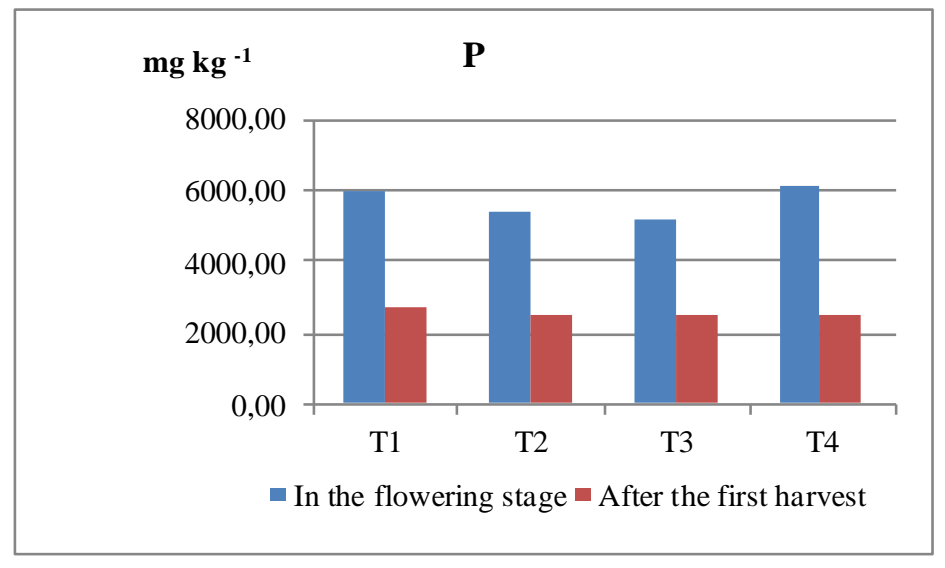

Figure 3. Phosphorus content of strawberry leaves at two different sampling times for 4 different seaweed doses. 
Potassium is one of the major nutrients for plant survival and is involved in activation of the meristematic tissue growth, water transport and photosynthesis (Mengel and Kirkby, 1987). The results of ANOVA indicated that seaweed doses did not have significant affect on $\mathrm{K}$ concentrations of strawberry leaves (Figure 4). The highest $\mathrm{K}$ concentration was obtained in $\mathrm{T} 4$ at flowering stage and the lowest $\mathrm{K}$ value was in T3 treatment at flowering stage. The highest $\mathrm{K}$ content in the second sampling was recorded in T3, while the lowest value was in T4 treatment. The $\mathrm{K}$ content of strawberry leaves was significantly different $(\mathrm{p}<0.01)$ between the sampling periods. The $\mathrm{K}$ concentration of leaves in the flowering stage $\left(20155.3 \pm 782.19 \mathrm{mg} \mathrm{kg}^{-1}\right)$ was higher compared to $\mathrm{K}$ content recorded after the first harvest $\left(15505.2 \pm 782.19 \mathrm{mg} \mathrm{kg}^{-1}\right)$. Battacharyya et al. (2015), had been found similar results to our results in their experiment.

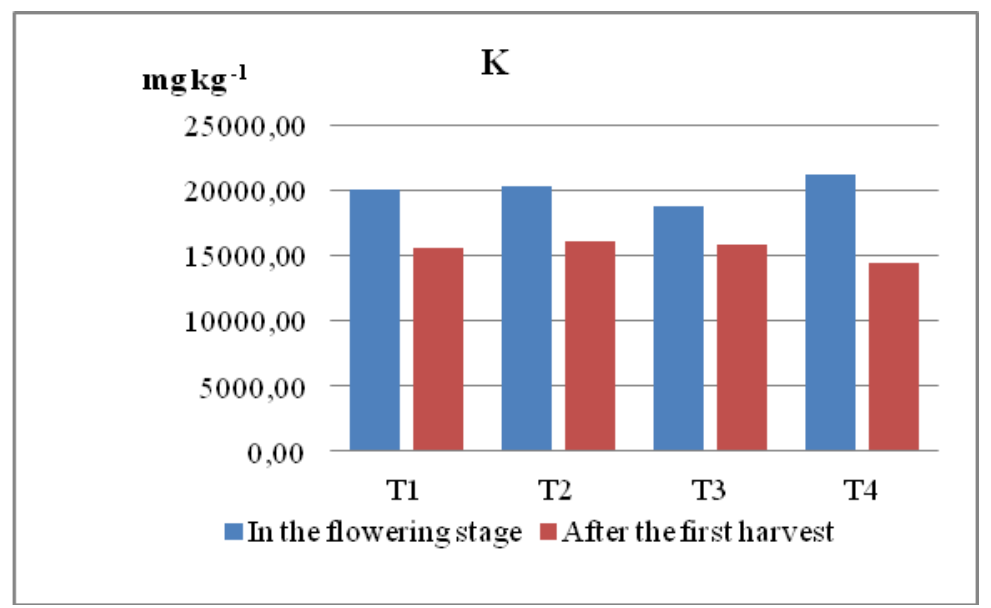

Figure 4. Potassium content of strawberry leaves at two different sampling times for 4 different seaweed doses.

Magnesium is the key nutrient of chlorophyll production, improves the mobility of $\mathrm{P}$, increases the activity and components of some plant hormones; influences earliness and uniformity of the fruit maturity. Tavasoli et al. (2010) showed that $\mathrm{Mg}$ increases the fruit yield due to the influence on the intensity of photosynthesis different doses of seaweed (Alga 600) had no significant effect on Mg concentration of strawberry leaves as similar to our study in Figure 5. The concentration of $\mathrm{Mg}$ in T4 and T2 treatments were higher compared with the control, and the highest value was recorded in T4 treatment at flowering stage. The highest $\mathrm{Mg}$ content in the second sampling was obtained in T3 treatment while the lowest value was in T4 treatment. The concentration of $\mathrm{Mg}$ was significantly different $(\mathrm{p}<0.01)$ between the sampling periods (Table 3$)$. The highest $\mathrm{Mg}$ value was recorded after the first harvest $\left(6487.06 \pm 212.56 \mathrm{mg} \mathrm{kg}^{-1}\right)$ and the lowest value was in the flowering stage $\left(3380.43 \pm 212.56 \mathrm{mg} \mathrm{kg}^{-1}\right)$.

The effects of different doses of seaweed extracts on Ca concentration of strawberry leaves was presented in Figure 6. The seaweed doses had no significant effect on $\mathrm{Ca}$ concentration of leaves. The concentration of $\mathrm{Ca}$ in $\mathrm{T} 2$ and $\mathrm{T} 4$ treatments was higher compared with the control. The highest $\mathrm{Ca}$ concentration was recorded in $\mathrm{T} 4$ treatment at flowering stage while the lowest value in control at flowering stage. In the second sampling, the highest value was obtained in control and the lowest value was in T2 treatment. The concentration of Ca was significantly different $(\mathrm{p}<0.01)$ between the 
sampling periods. The highest $\mathrm{Ca}$ concentration was recorded after the first harvest $\left(1281.56 \pm 35.10 \mathrm{mg} \mathrm{kg} \mathrm{kg}^{-1}\right)$ and the lowest value was at the flowering stage $\left(490.88 \pm 35.10 \mathrm{mg} \mathrm{kg}^{-1}\right)$. Rathore et al. (2009), had also been determined close results to ours in their research.

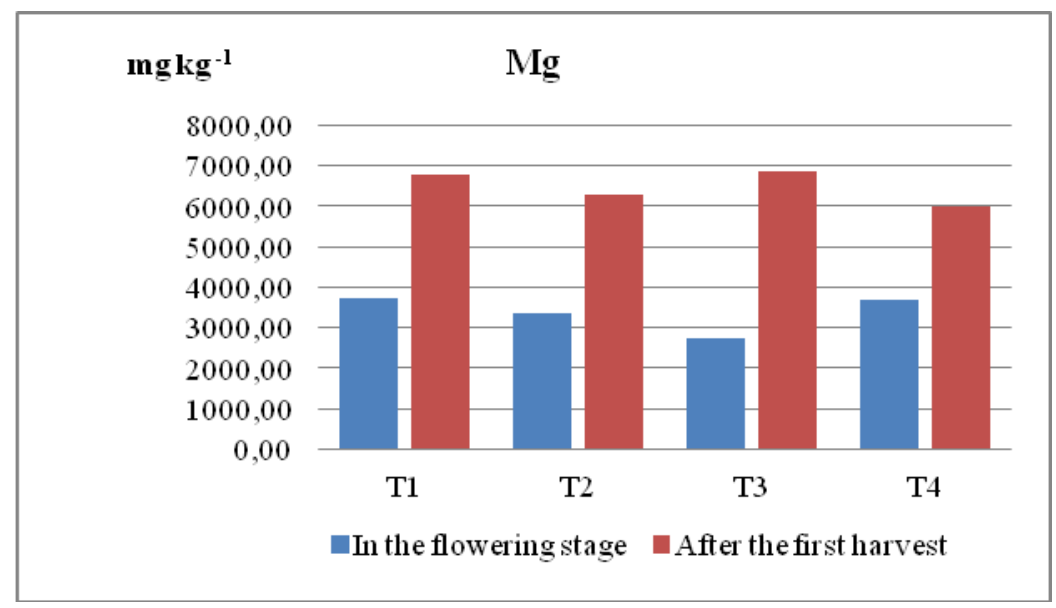

Figure 5. Magnesium content of strawberry leaves at two different sampling times for 4 different seaweed doses.

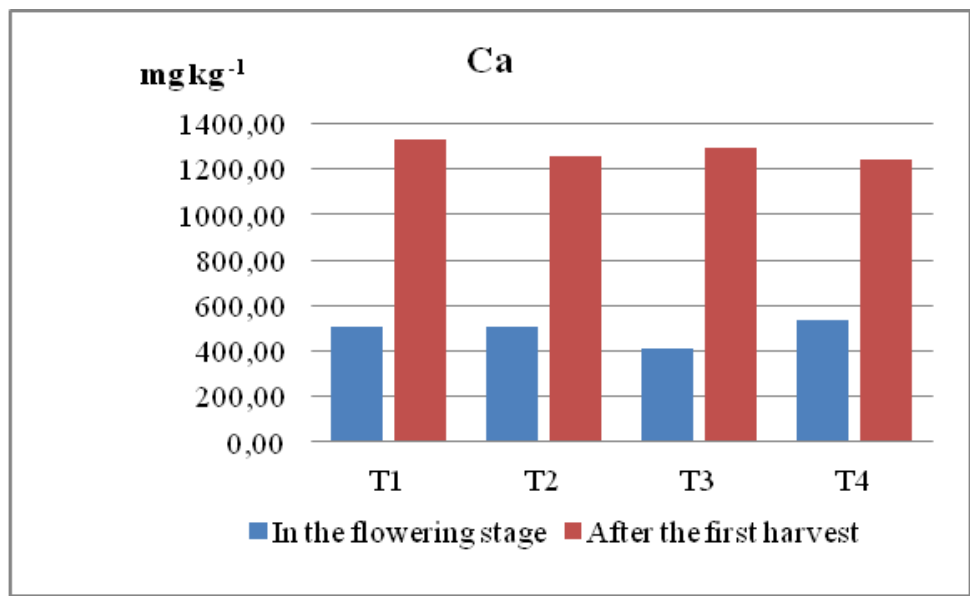

Figure 6. Calcium content in strawberry leaves at two different sampling times for 4 different seaweed doses.

\section{Micronutrient Concentrations of Strawberry Leaves}

The results of ANOVA test conducted to determine the effects of seaweed treatments on $\mathrm{Mn}$ concentration of strawberry leaves were given in Figure 7. The seaweed application significantly $(\mathrm{p}<0.05)$ increased the Mn concentration of leaves and the $\mathrm{Mn}$ concentrations of leaves increased with increasing doses of seaweed. The highest $\mathrm{Mn}$ value was recorded in T4 while the lowest value was in $\mathrm{T} 1$ at flowering stage. In the first harvest, the Mn concentration of leaves increased with higher doses of seaweed though the changes were not significant. The highest Mn content after the first harvest was obtained with T4 treatment and the lowest value was in T1 treatment. Statistically significant difference $(\mathrm{p}<0.01)$ was observed in Mn concentration of leaves between the 
sampling periods. The concentration of leaves after the first harvest was significantly higher $\left(242.09 \pm 8.19 \mathrm{mg} \mathrm{kg}^{-1}\right)$ than the Mn concentration recorded in the flowering stage $\left(131.30 \pm 8.19 \mathrm{mg} \mathrm{kg}^{-1}\right)$. The increase in $\mathrm{Mn}$ concentration of leaves can be attributed to the high micronutrient concentration of seaweed used in this study. Fertigation of seaweed improved the Mn uptake by root system. Kumari et al. (2011) reported higher vegetative growth, yield and pest resistance with liquid spray application of seaweed. Similarly, Crouch and Staden (1992) showed that seaweed enhanced the root growth and had positive effect on nutrient uptake such as Mn.

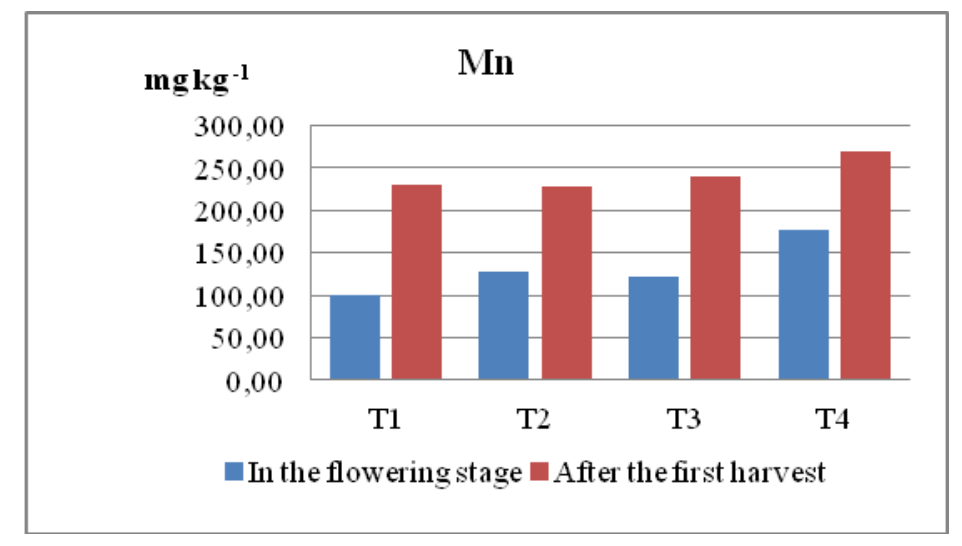

Figure 7. Manganese content in strawberry leaves at two different sampling times for 4 different seaweed doses.

The effect of seaweed doses on Fe concentration of strawberry plants were shown in Figure 8. The seaweed doses did not have a significant effect on Fe concentration of leaves. The concentration of Fe in T1 and T4 treatments were higher compare to the T2 and T3 treatments. The highest value was recorded in control at the flowering stage and the lowest value was in T2 treatment at flowering stage. In second sampling, the highest value was obtained with T4 treatment and the lowest value was in control. The concentration of Fe recorded after the first harvest $\left(484.77 \pm 13.02 \mathrm{mg} \mathrm{kg}^{-1}\right)$ was significantly $(\mathrm{p}<0.01)$ higher than the Fe concentration obtained in the flowering stage $\left(267.62 \pm 13.02 \mathrm{mg} \mathrm{kg}^{-1}\right)$. Similarly, Rathore et al. (2009), had been highlighted close results to our study.

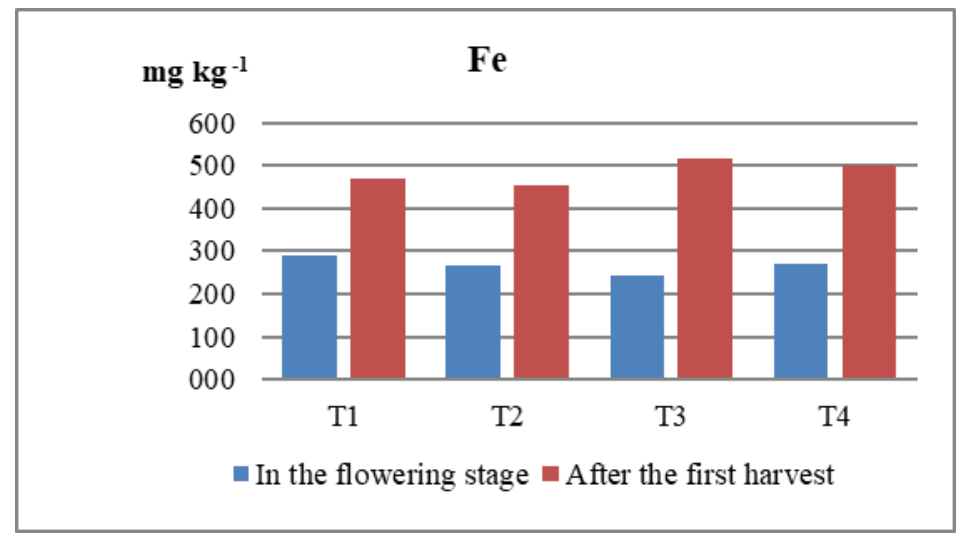

Figure 8. Iron content in leaf of strawberry leaves at two different sampling times for 4 different seaweed doses. 
The seaweed treatments had no significant effect on $\mathrm{Cu}$ concentrations of strawberry leaves (Figure 9). The concentration of $\mathrm{Cu}$ in control treatment was higher than the $\mathrm{Cu}$ contents recorded in seaweed applications. The highest $\mathrm{Cu}$ concentration in flowering stage was recorded in control and the lowest value was obtained in T2 at the flowering stage. Similarly, the highest $\mathrm{Cu}$ concentration in the second sampling was recorded in $\mathrm{T} 1$ treatment. The $\mathrm{Cu}$ concentration of strawberry leaves recorded in flowering stage $\left(3.17 \pm 0.14 \mathrm{mg} \mathrm{kg}^{-1}\right)$ was slightly lower compared to the $\mathrm{Cu}$ concentration recorded after the first harvest $\left(3.22 \pm 0.14 \mathrm{mg} \mathrm{kg}^{-1}\right)$. Shehata et al. (2011), had also been found similar findings to our experiment.

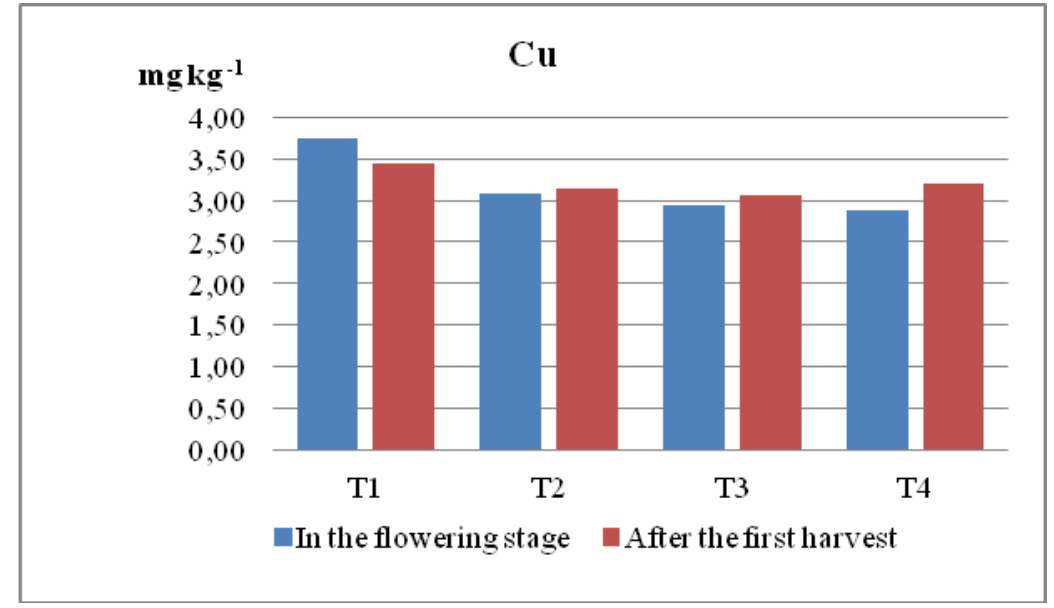

Figure 9. Copper content in leaf of strawberry leaves at two different sampling times for 4 different seaweed doses.

$\mathrm{Zn}$ has been reported causing higher fruit yield due to the positive effects on the intensity of photosynthesis (Tavasoli et al., 2010). The seaweed treatment did not significantly affect the $\mathrm{Zn}$ concentration of strawberry leaves. The lowest $\mathrm{Zn}$ concentration was obtained with T3 treatment, while the highest value was recorded in $\mathrm{T} 4$ at flowering stage. In contrast to the flowering stage, the highest $\mathrm{Zn}$ concentration after the first harvest was obtained with T3 and the lowest value was in T2 treatment. The concentration of $\mathrm{Zn}$ at two different sampling periods was significantly different $(\mathrm{p}<0.01)$. The $\mathrm{Zn}$ concentration in flowering stage $\left(31.90 \pm 1.65 \mathrm{mg} \mathrm{kg}^{-1}\right)$ was higher than the $\mathrm{Zn}$ concentration recorded after the first harvest $\left(29.70 \pm 1.65 \mathrm{mg} \mathrm{kg}^{-1}\right)$, though the difference was not statistically significant (Figure 10).

Soil quality in undeveloped and developing countries deteriorates due to the lack of proper fertilization techniques or over-fertilization. In appropriate fertilization causes losing the fertility of agricultural lands and the sustainability of soils and nature. In some cases, a lack of sufficient fertilization results in low yield in agricultural lands. Fertilization and productivity have a close relationship in agriculture. For healthy plant growth, sufficient and balanced amount of plant nutrients must be present in soils. On the other hand, the availability of nutrients for plant uptake is extremely important for the plants to benefit sufficiently from the nutrients in the soil. Several factors such as soil structure, plant type, and climate affect the ability of plants to benefit from fertilizers applied to soil (Özbek, 1970). The use of organic fertilizers such as seaweed instead of chemical inputs should be expanded to maintain a sustainable production 
system that protects the environment and natural resources in the long term. Recent scientific studies also support these views (Khan et al., 2009; Craigie, 2011; Calvo et al., 2014; Arioli et al., 2015).

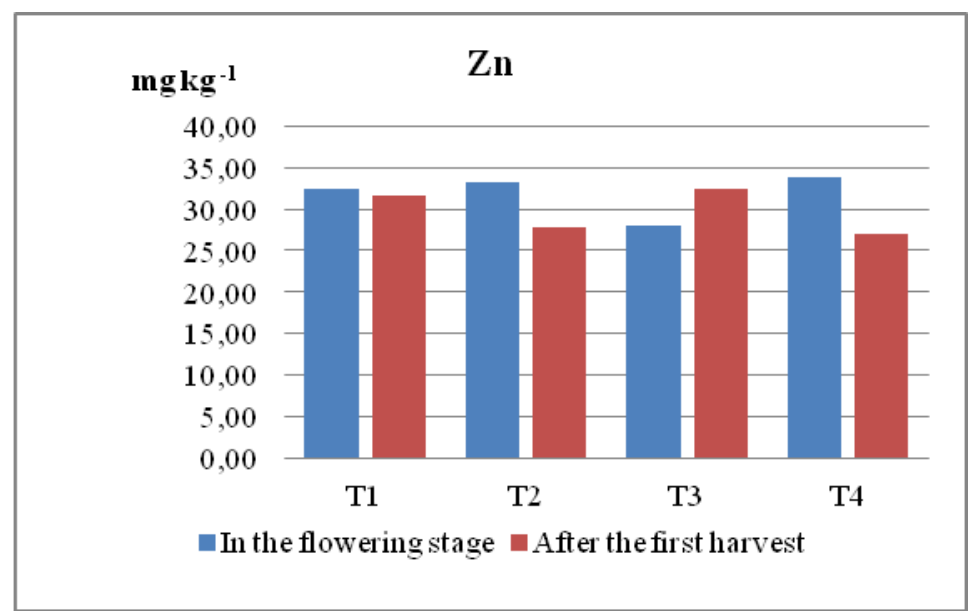

Figure 10. Zinc content in leaf of strawberry leaves at two different sampling times for 4 different seaweed doses.

\section{Conclusion}

This study was conducted to investigate the effects of seaweed (Alga 600) on nutrient uptake of strawberry cv. Albion. Following conclusions can be drawn from the results obtained in this study. The concentrations of $\mathrm{N}, \mathrm{P}, \mathrm{K}, \mathrm{Mg}, \mathrm{Ca}, \mathrm{Mn}$ and $\mathrm{Fe}$ in strawberry leaves recorded in two different sampling periods (flowering and after the first harvest) were significantly different from each other. Consequently, it was pointed according to the result of the two-way analysis of variance, the effect of seaweed doses on nutrients were statistically insignificant for all nutrients except $\mathrm{Mn}$ ( $\mathrm{p}>0.05)$ (Table 3). While the Mn element, the higest value $\left(223.70 \pm 11.59 \mathrm{mg} \mathrm{kg}^{-1}\right)$ obtained from T4 $\left(8 \mathrm{~g} . \mathrm{L}^{-1}\right)$ seaweed dose; the lowest value $\left(164.91 \pm 11.59 \mathrm{mg} \mathrm{kg}{ }^{-1}\right)$ obtained from control dose. The effect of interaction between seaweed doses and periods on nutrients was also not found statistically significant ( $p>0.05)$. As shown in Table 4, the effect of fertilizer application periods on $\mathrm{N}, \mathrm{P}, \mathrm{K}, \mathrm{Mg}, \mathrm{Ca}, \mathrm{Mn}$ and Fe elements were significant statistically except $\mathrm{Cu}$ and $\mathrm{Zn}$ elements. In general, the seaweed (Alga 600) do not have a significant effect on macro and micro nutrient contents of leaves. Seaweed fertigation significantly increased the $\mathrm{Mn}$ contents of leaves at both application periods. In general, seaweed extract of 8 g.L. $\mathrm{L}^{-1}$ was more effective on macro and micro nutrient contents of strawberry leaves. Higher $\mathrm{N}, \mathrm{P}, \mathrm{K}, \mathrm{Mg}, \mathrm{Ca}, \mathrm{Mn}$ and $\mathrm{Fe}$ concentrations were recorded respectively; $2.94 \pm 0.13 \mathrm{mg} \mathrm{kg}^{-1}, 4277.42 \pm 258.25 \mathrm{mg}$ $\mathrm{kg}^{-1}, 17857.60 \pm 1106.18 \mathrm{mg} \mathrm{kg}^{-1}, 4851.53 \pm 300.60 \mathrm{mg} \mathrm{kg}^{-1}, 887.16 \pm 49.64 \mathrm{mg} \mathrm{kg}^{-1}$, $223.70 \pm 11.59 \mathrm{mg} \mathrm{kg}^{-1}, 385.73 \pm 18.41 \mathrm{mg} \mathrm{kg}^{-1}$ in $\mathrm{T} 4$ treatment after the first seaweed application.

As a result of this study carried out in Iraq, which tries to strengthen agriculture, industry, and economy after the war, is thought to lead the expanding of strawberry production in the region, improving the strawberry cultivation with superior yield and quality characteristics and adopting the environmentally friendly production techniques. 
Acknowledgement. This article is produced from the MSc Thesis belongs to A.H.N. AL-SHATRI and the thesis has been funded with the project (2017-SIUÜFEB-90) by Scientific Research Projects Council, Siirt University.

\section{REFERENCES}

[1] Abdulraheem, S. M. (2009): Effect of nitrogen fertilizer and seaweed extracts on vegetative growth and yield of cucumber. - Diyala Agric. Sci. J. 1: 134-145.

[2] Anonymous (2017): Statistical data. - Agrometeorology Directorate, Sulaymaniyah/Iraq. Access Date: August 10, 2017.

[3] Arioli, T., Mattner, S. W., Winberg, P. C. (2015): Applications of seaweed extracts in Australian agriculture: past, present and future. - J Appl Phycol 27: 2007-2015.

[4] Battacharyya, D., Babgohari, M. Z., Rathor, P., Prithiviraj, B. (2015): Seaweed extracts as biostimulants in horticulture. - Scientia Horticulturae 196: 39-48.

[5] Blevins, J. P. (1999): Productivity and exponent. - Behavioral and Brain Sciences 22(6): 1015-1016.

[6] Blunden, G. (1991): Agricultural Uses of Seaweeds and Seaweed Extracts. - In: Guiry, M. D., Blunden, G. (eds.) Seaweed Resources in Europe: Uses and Potential. John Wiley and Sons. p. 65-81.

[7] Blunden, G., Whapham, C., Jenkins, T. (1992): Seaweed Extracts in Agriculture and Horticulture: Their Origins, Uses and Modes of Action. School of Pharmacy and Biomedical Science and School of Biological Sciences. - University of Portsmouth, King Henry John Street, Portsmouth, Hampshire P01 202, U.K.

[8] Calvo, P., Nelson, L., Kloepper, J. W. (2014): Agricultural uses of plant biostimulants. - Plant Soil 383: 3-41.

[9] Craigie, J. S. (2011): Seaweed extract stimuli in plant science and agriculture. - J Appl Phycol 23: 371-393.

[10] Crouch, I. J., Staden, J. V. (1992): Effect of seaweed concentrate on the establishment and yield of greenhouse tomato plants. - Journal of Applied Phycology 4(4): 291-296.

[11] Darrow, G. M. (1966): The Strawberry: history, breeding and physiology. - Holt, Rinehart and Winston, New York, Chicago. 447 p.

[12] Güner, H., Aysel, V. (1996): Systematics of seedless plants. Vol. 1 Algae. - Ege University Science Faculty Books Series. No. 108. Bornova, İzmir. (in Turkish).

[13] Hong, Y. P., Chen, C. C., Cheng, H. L., Lin, C. H. (1995): Analysis of Auxin and Cytokinin Activity of Commercial Aqueous Seaweed Extract. Gartenbauwissenschaft 60(4): 191-194.

[14] Kaçar, B., İnal, A. (2008): Plant analysis. - Nobel publication No: 1241. (in Turkish).

[15] Katiyar, P. N., Singh, J. P., Singh, P.C. (2009): Effect of mulching on plant growth, yield and quality of strawberry under agro-climatic conditions of Central Uttar Pradesh. - International Journal of Agricultural Sciences 5(1): 85-86.

[16] Khan, W., Rayirath, U. P., Subramanian, S., Jithesh, M. N., Rayorath, P., Hodges, D. M., Critchley, A. T., Craigie, J. S., Norrie, J., Prithiviraj, B. (2009): Seaweed extracts as biostimulants of plant growth and development. - J Plant Growth Regul 28: 386-399. 
[17] Kumari, R., Kaur, İ., Bhatnagar, A. K. (2011): Effect of aqueous extract of Sargassum johnstonii Setchell \& Gardner on growth, yield and quality of Lycopersicon esculentum Mill. - Journal of Applied Phycology 23(3): 623-633.

[18] Lantz, W., Swartz, H., Demchak, K., Frick, S. (2010): Season-long strawberry production with ever bearers for northeastern producers. - University of Marryland Extension, p.11.

[19] Margarida, C. A., Villas Boas, T. M., Mota, V. S., Silva, C. K. M., Poveda, V. B. (2014): Microbial Contamination of Jackets Firsts During Health Care. Brazilian Journal of Nursing 67. (In French).

[20] Mengel, K., Kirkby, E. A. (1987): Potassium. - In: Principles of Plant Nutrition. Intern. Potash Institute: 427-446. Basel, Switzerland.

[21] Rathore, S. S., Chaudhary, D. R., Boricha, G. N., Ghosh, A., Bhatt, B. P., Zodape, S. T., Patolia, J. S. (2009): Effect of seaweed extract on the growth, yield and nutrient uptake of soybean (Glycine max) under rain fed conditions. - South African Journal of Botany 75(2): 351-355.

[22] Schmidt, R. E., Ervin, E. H., Zhang, X. (2003): Questions and answers about biostimulants. - Golf Course Management 71: 91-94.

[23] Sharma, R. R. (2002): Growing strawberry. - Int. Book Distributing Co., India 1: 01-02.

[24] Shehata, S. M., Abdel-Azim, H. S., El-Yazied, A. A., El-Gizawy, A. M. (2011): Effect of foliar spraying with amino acids and seaweed extract on growth chemical constitutes, yield and its quality of celeriac. - Plant. Euro. J. Sci. Res. 58(2): 257-265.

[25] Tavasoli, A., Ghanbari, A., Ahmadian, A. (2010): The effect of magnesium and zinc nutrition on the fruit yield and nutrient concentrations in greenhouse tomato Hydroponic cultivation. - J. Sci. Technol. Greenhouse Plantation 1: 1-5. 